\title{
Experiences of a Fulbright Scholar
}

\section{Experiencia de una becaria Fulbright, ensayo de opinión}

\section{VICTORIA ISABEL CARRASCO TORAL}

victoriaicarrasco@hotmail.com

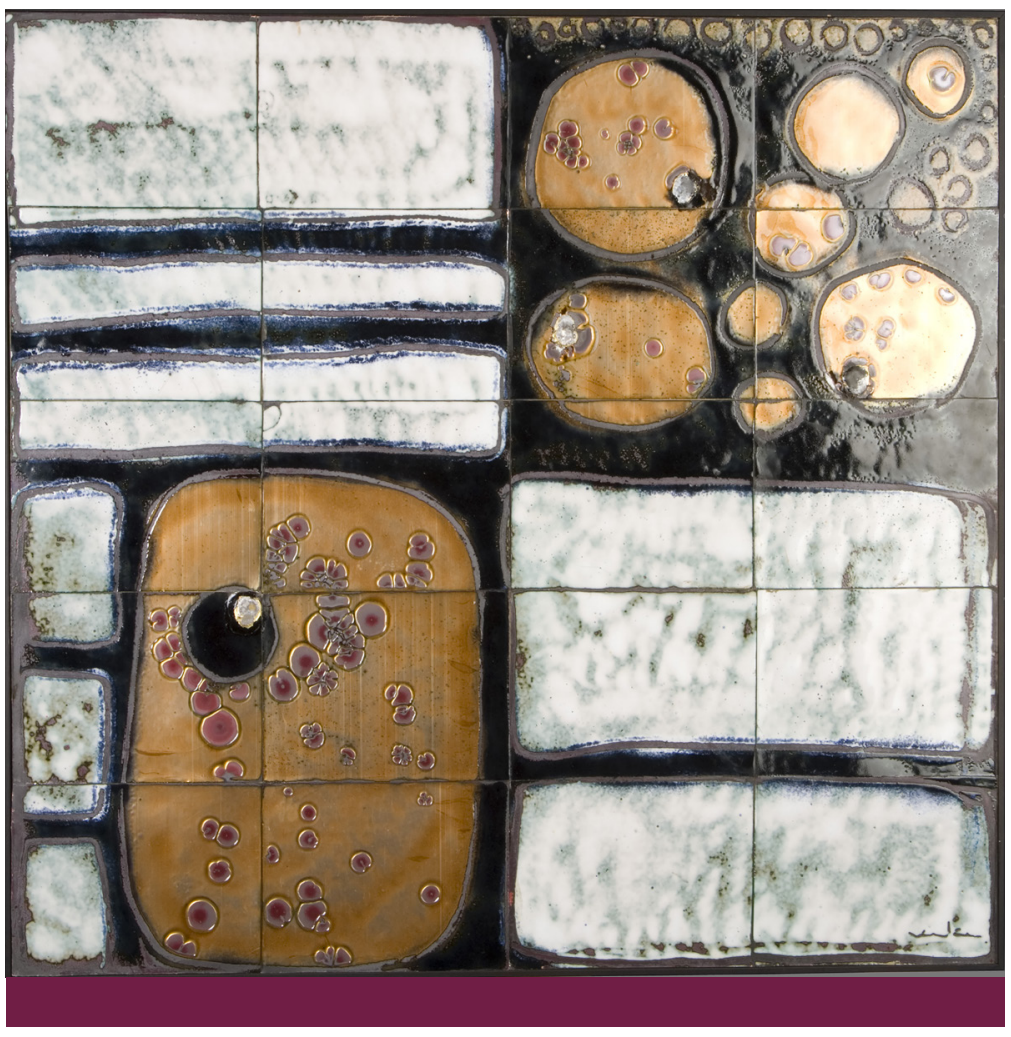

My time spent as a Fulbright Scholar was quite an experience. Learning about United States culture and sharing my Latin American roots with my American friends was a great adventure. I discovered that Eastern Kentucky is rich in Folk Art tradition. Wood carvings, weaving and spinning, painting, quilts, basket weaving, etc., all impressed me. I did not expect such a rich culture.

Even though this cultural exchange was challenging, I also found that people from Kentucky showed a great understanding and appreciation of my work. We share the fact that we both come from very strong, albeit different, traditions.

Latin-American Folk Art has many similarities with artistic expressions found in Eastern Kentucky. These include rich colors, shapes and meanings.

For example, I studied the work of Dennis Goodpaster, a native of Morehead, Kentucky who crafts walking sticks. I discovered that Mr. Goodpaster's work was similar to many of the folk artists I have encountered all over the world. He embraces his natural environment and uses themes and bright colors from his everyday life in his work. 
I also had the opportunity to work with Granny Toothman, a weaver who uses many types of natural fibers. We exchanged several ideas and techniques. However, the greatest positive cultural shock occurred while I was teaching Folk Art at Morehead State University (MSU). My students were very interested in my background, the origins of Latin American Culture and particularly, preColumbian and Inca influences.

My weaving classes were very special to me. The students were very enthusiastic, and I developed very positive relationships with them. They were very interested in using fibers, colors, textures and techniques. Even though they came from a different culture than my own, all of them were very open-minded and warm. Indeed, we found that we share common influences and backgrounds from which to build on. Overall, my teaching experience was great.

In addition to my students, there were several other people I worked with at MSU who were very instrumental in making my stay a very pleasant experience. Dr. Judy Rogers, Dean of Undergraduate Studies, helped coordinate my program. She was a smart and professional woman, who organized my program extremely well. She arranged my schedule and teaching duties and planned an exhibition of my artwork. She organized my visits to other universities and high schools in the area and introduced me to other artists who helped me in various ways. She made herself available to work with me whenever any difficulties arose and was very friendly and warm. She was essential in making my stay a tremendous success. Dr. Rogers' secretary, Carolyn Hensley, was a tremendous help to me as well, always very friendly and willing to work with me. Dr. Roger Jones, a Professor of Art at MSU, also acted as coordinator of my program. Dr. Jones worked closely with me and became a liaison in scheduling my activities.

Two of the first friends I met in Morehead were Dr. Vicente and Sara Cano. They teach Spanish and invited me into their home and into their classrooms to speak about my culture. We not only developed a professional relationship but also became great friends.

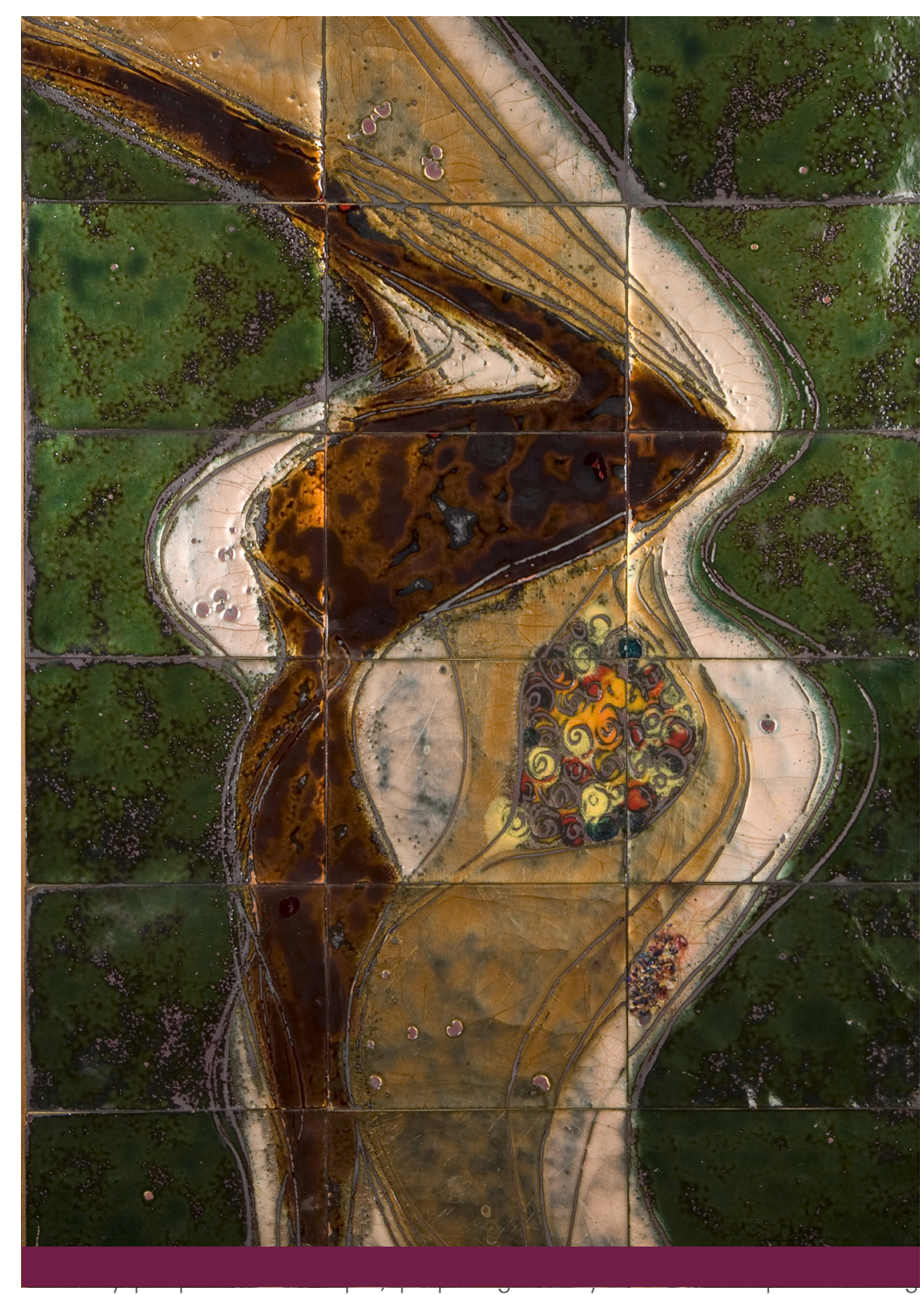



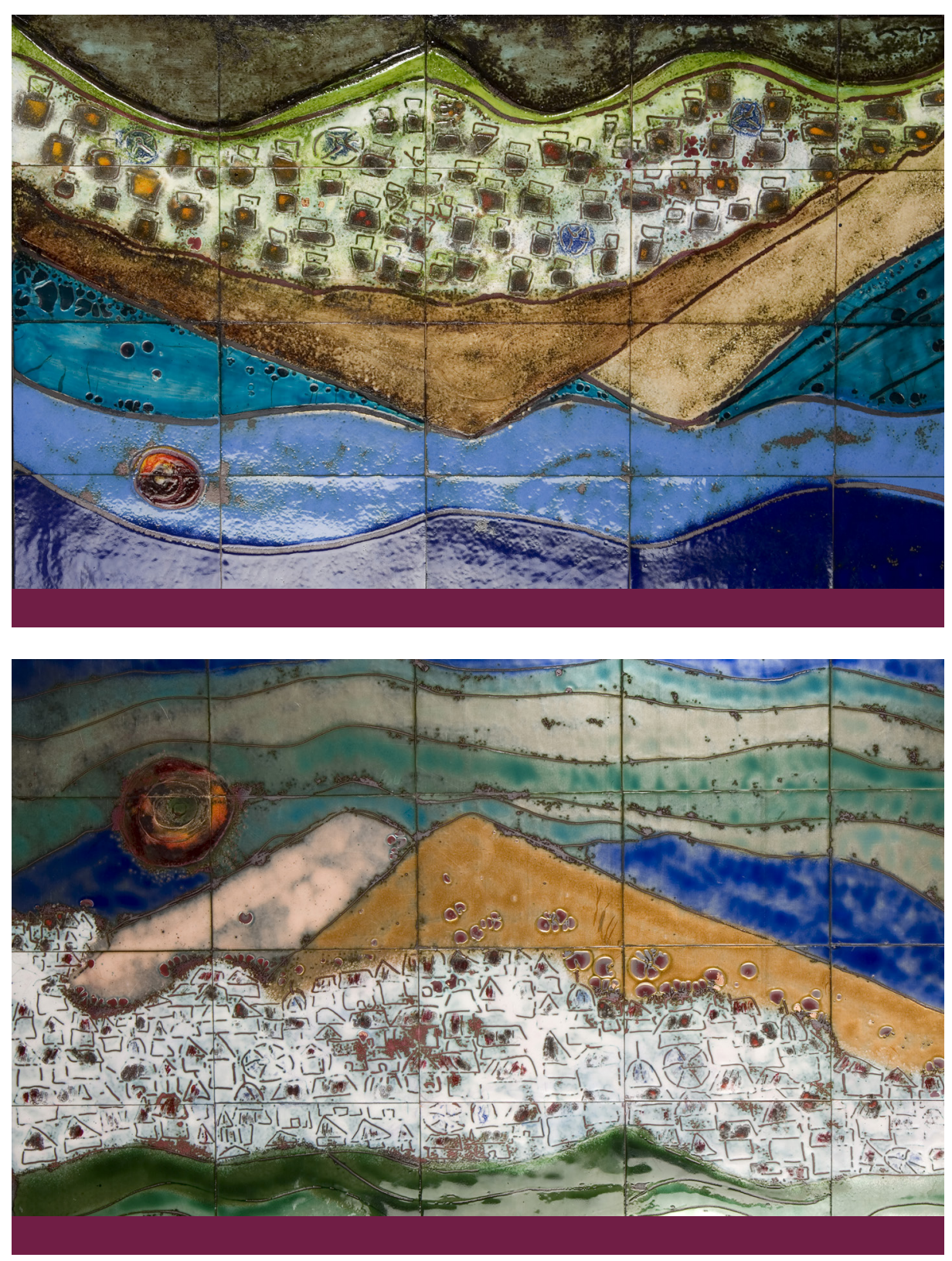

wood and metal and assembly of my art project. I had to do it all by myself. In Ecuador, on the other hand, my assistants would have done all the groundwork. That was really an extraordinary and life-enriching experience as an artist and craftswoman.

I am grateful that the Fulbright Scholarship gave me the opportunity to share my culture and my work. I hope that showing Latin American Culture to the people of this region of the United States was of equal value to Morehead State University. I enjoyed the exchange of cultural art, education, and ideas. This was a very positive experience for me, as an educator and artist, as well as a human being.

I was lucky enough to get a second opportunity to teach and work in the US as a Fulbright Scholar at Oklahoma City Community College from 1998 to 1999. My experience provided many opportunities for the exchange of ideas and cultural experiences. I feel that I gained a much greater understanding of North American culture as a result of my stay there. All the lectures were a learning experience for both my students and myself. Although there are many differences between the educational systems of the US and Ecuador, I shared with my colleagues the same goals of instilling a love for the arts and encouraging creativity.

In addition to the cultural and academic benefits of my stay, I had the opportunity to meet and get to know many people whose kindness and generosity enriched my experience in Oklahoma. I left behind many friends when I returned to Ecuador. I want to give special thanks to Dr. Robert Todd, President of Oklahoma City Community College; Dr. Paul Sechrist, Vice President for Academic Affairs; and Susan VanSchuyver, Acting Dean of Arts and Humanities. Several faculty colleagues organized events and provided guidance, support and friendship, in particular, Caroline Farris, Professor of Visual Arts; and Patricia J. Brooks and Dianne Broyles, Professors of Modern Languages. Other colleagues were also helpful and supportive: Abra Glenn-Allen Figueroa, Professor of English as a Second Language; Mary Ann Moore, Professor of Visual 
Arts; and Dr. Richard Rouillard and Bertha Wise, Professors of English and Humanities. The office staff of the Division of Arts and Humanities, Sherry Hobbs and Rochelle Mosby, did far more than what was required in order to keep events running smoothly.

I had many contacts with the large community, including presentations at public and private high schools and colleges and visits to museums and galleries. I became acquainted with many local artists and had the opportunity to view their works and engage in discussions of the process of artistic creation. The Division of Arts and Humanities arranged an exhibit of my work at the Oklahoma City Community College library and the opening was attended by artists from the community as well as college faculty and students. There was much favorable response to my work, and several pieces were sold. In addition, I donated two large works, one to the college and the other to a medical facility. It is gratifying to know that after I left Oklahoma, many people would view these works and would respond to my creative efforts.
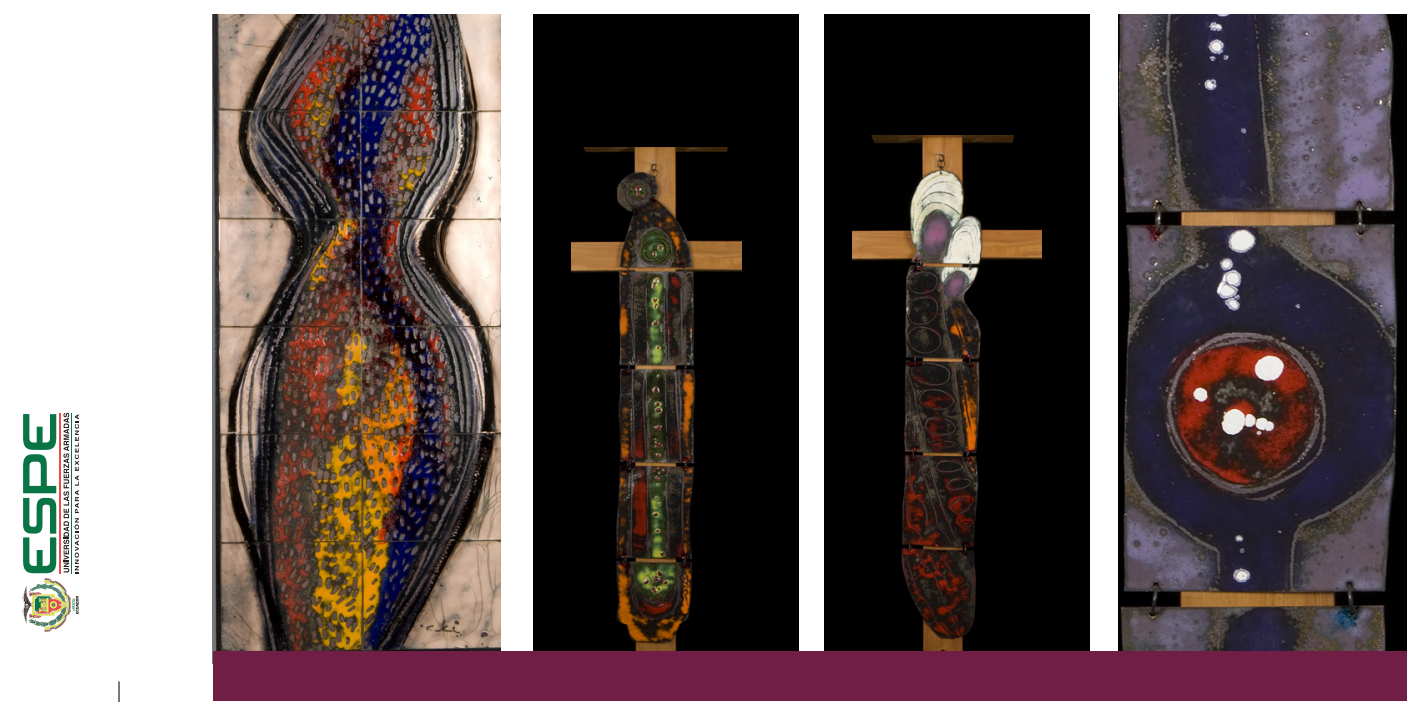

\section{VICTORIA ISABEL CARRASCO TORAL}

victoriaicarrasco@hotmail.com

\section{Experiencia Profesional:}

- Profesora Facultad de Artes Universidad Central del Ecuador 1973-2006

- Profesora Visitante. Universidad de Barcelona, España. 2003

- Decana Facultad e Artes Universidad Central del Ecuador. 19982002

- Fubright Scholar, Profesora visitante.

Oklahoma University, USA. 1998

- Vicedecana Facultad de Artes Universidad Central del Ecuador. 1994-1998

- Fubright Scholar, Profesora visitante. Monehead State University, USA. 1991-1992

\section{Educación:}

- Academia de Bellas Artes, Cuenca-Ecuador. 1961-1966

- Decoración Interior, Cuenca-Ecuador. 1965-1967

- Curso de Artes, Bruselas-Bélgica. 1967-1968

- Curso de Esmaltes en Cobre, Colonia-Alemania. 1968-1969

- Curso de Textiles, Praga-República Checa. 1975-1976

Curso de Arte, Roma-Italia 1985

\section{Exposiciones:}

- Galería Larrazabal Cuenca-Ecuador 2009

- Galería Sebastián, México D.F.-México. 2008

- Cienfuegos-Cuba. 2007

- Galería CAF, Caracas

$$
\text { Venezuela. } 2006
$$

- Madrid-España. 2003

- AMTUNEL, París-Francia. 2003

- "100 Artistas", Libro Ministerio RREE, QuitoEcuador. 2002

- Galería Oklahoma University, Oklahoma-USA. 1998

- Victoria and Albert, LondresInglaterra. 1974

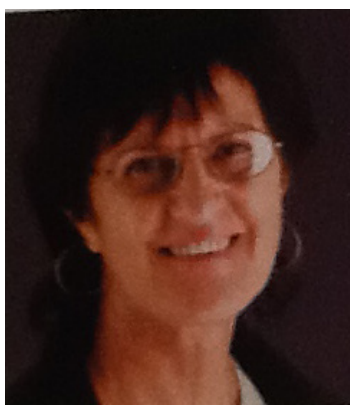

